\title{
Internationalization and "Go-Global" Strategies of Enterprises in Jiaxing City, Zhejiang Province, PRC
}

\author{
Junjie Zhang ${ }^{1} \&$ Xiajing Dai ${ }^{1}$ \\ ${ }^{1}$ Business School, Jiaxing University, Jiaxing, China \\ Correspondence: Junjie Zhang, Business School, Jiaxing University, $56^{\text {th }}$ South Yuexiu Road, Jiaxing City, \\ Zhejiang Province, China. Tel: 86-573-8364-2515. E-mail: junjiezhanguk@163.com
}

Received: March 1, 2013

Accepted: March 18, 2013

Online Published: April 17, 2013

doi:10.5539/ibr.v6n5p133

URL: http://dx.doi.org/10.5539/ibr.v6n5p133

\begin{abstract}
This research is financially supported by 2012 Zhejiang Social Science Association project- "county level small to medium enterprises' fund raising and financial support research in Zhejiang province, China-based on analysis of transaction cost" (Project No. 2012N135) and the authors greatly acknowledge their financial assistance for this research.
\end{abstract}

\begin{abstract}
The macro-environment of "post-financial crisis and twelfth five-year planning period" greatly influences Jiaxing enterprises' formulation and implementation of their internationalization and "go-global" strategies. The paper tries to explore Jiaxing enterprises' development path and trend of internationalization from their "go-global" motives, modes, entry location, existed problems and solution aspects. The paper also selects a bundle of Jiaxing enterprises which have successfully implemented "go global" strategy as case studies for deep analysis. The paper argues that some Jiaxing enterprises follow western traditional FDI theories in their internationalization process while others managed to flexibly utilize new trends of globalization and interconnected world economy, accelerate their internationalization process, which can not be fully explained by traditional FDI theories. Meanwhile, the journey of Jiaxing enterprises' internationalization filled with various challenges, the paper also discusses those challenges and problems existed and some targeted solution approaches have also been provided.
\end{abstract}

Keywords: Jiaxing enterprises, internationalization, go-global strategy

\section{The Research Background and Significance}

Global financial crisis incurred by Wall Street sub-mortgage crisis burst out in August, 2007 had swept the entire world with its gigantic destructive forces, the world economy entered into "epoch of post-crisis" in 2011, and this process would at least last in future 5 years. (Hanjie, 2010) World economic structure has transformed to a great deal in "epoch of post-crisis": serious economic problems have occurred in Western developed countries led by USA, especially, manufacturing industries also decline obviously. While emerging economies were seriously affected by developed countries' economic stagnation on one hand, opportunities of reshuffling their own industrial structures, transforming and upgrading their own economies, "go-global" to merge and acquire invaluable strategic assets overseas have also emerged on the other hand. Some scholars believe that post financial crisis period will lead to deep transformation of Chinese economy and nurture the hope for Chinese companies to expand new territories in the world. (ZhaoWei, 2010) Prices of world energy and raw materials declined, overseas enterprises' bankruptcy and restructuring have brought new opportunities for Chinese enterprises to invest in; China's overall economy's continued growth has enhanced and exemplified its voice in international negotiation, which adds advantageous factors to Chinese enterprises' internationalization. In order to effectively cope with all sorts of opportunities and threats in "epoch of post-crisis", CPCC has formulated "The twelfth five year planning", CPCC Zhejiang Committee has put forward "Suggestions on formulating the twelfth five year planning in Zhejiang province", advocated more proactive development strategies and "go global" strategies to enhance economic competencies. According to statistics, Zhejiang province is just in the period of GDP per capita rapid growth from $\$ 6000$ to $\$ 10000$, private business are very thriving and manufacturing capabilities are very strong in Zhejiang province, thus, forcefully to implement "go-global" strategy will embrace an invaluable development opportunity. 
According to Zhejiang commerce department's statistics, overseas investment from firms in Zhejiang province had boosted very quickly in "the eleventh five year" period, firms take cross-border M\&A and industrial investment as the key point, the overseas investment projects had reached to 2236 units with total sum of $\$ 5.7$ billion, the number of firms undertake overseas investment had ranked No.1 in China. OFDI from Zhejiang province maintained rapid growth momentum especially in three years after financial crisis erupted, the amount of OFDI in Zhejiang province boosted from $\$ 0.86$ billion in 2008 to 2.7 billion in 2010, annual growth rate has kept over $70 \%$, and it was over five times the total amount of overseas investment in "the tenth five year" period. In 2010, OFDI from Jiaxing hit new high, new authorized overseas investment projects rose to 50, the amount of OFDI capital reached to $\$ 159$ million, grew up 55\% year on year, up to the end of July in 2012, firms which have conducted OFDI have risen to 137. Jiaxing firms undertake OFDI in overseas distribution channels building, industrial top firms' acquisition, overseas construction projects' subcontracting, and agriculture or natural resources' investment, as the case stands, Jiaxing firms have also become a noticeable group among Zhejiang firms which go global successfully.

The paper tries to explore Jiaxing enterprises' development path and trend of internationalization from their "go-global" motives, modes, entry locations, existed problems and solution aspects, at the same time, the paper also selects a bundle of Jiaxing enterprises which have successfully implemented "go global" strategy as case studies for deep analysis. We hope some practical suggestions could be provided to Jiaxing firms for their more successful and adventurous foreign market expansion through those case studies analysis.

\section{Motives of Jiaxing Firms' Internationalization and "Go-Global"}

\subsection{Motives Follow Traditional FDI Theories}

Traditional FDI motives are mainly based on classical western FDI theories such as monopoly advantages by Hymer (Hymer, 1960), Internalization theory by Buckley and Casson (Buckley, Casson, 1976), Product life cycle theory by Vernon (Vernon, 1960) and Dunning's OLI paradigm (Dunning, 1988). The mainstream theories in international business assume that firms will internationalize on the basis of definable competitive advantages that allow them to secure enough return to cover the additional costs and risks associated with operating abroad (Buckley \& Ghauri, 1999; Caves, 1971). Among those theories, OLI paradigm put forwarded by John Dunning compromised previous theories in a concise way, OLI paradigm is acknowledged as a more comprehensive and pervasive explanation to why firms conduct OFDI. Dunning believed that the primary motives of firms undertaking OFDI were to take full advantage of their ownership advantages, location advantages and internalization advantages, which was known as "asset exploitation" type FDI. Dunning also categorized firms' OFDI motives into resource seeking, efficiency seeking, market seeking and asset seeking. (Dunning, 1988)

According to those theories' explanation, FDI which originated from developed countries can naturally flow to less-developed and developing countries to give full play of their ownership advantages and strategic assets, meanwhile, liabilities of foreignness could be effectively offset. Following that logic, FDI originated from less developed countries can flow to developing countries or even impoverished countries to take advantage of ownership advantages. In reality, there are some firms whose motives follow those traditional FDI theories, especially prominent to those natural resources seeking, market seeking and efficiency seeking firms in Jiaxing firms' case studies.

In the late "eleventh five year planning period", firms in Zhejiang province had gradually been deprived of so called three inexpensive factors (inexpensive labor, inexpensive land and inexpensive environment $\&$ resources) advantages which were once the vigorous boosters for economic growth in the past. Firms today have been confronted by increasingly higher labor cost, unusual stressful raw material and energy supplies with soared prices, therefore, undertaking foreign investment in countries where are endowed with much lower labor cost, more inexpensive and abundant resources, and larger low-end market demands which are still not met to realize synergy is considered as a wise decision.

Huayou Cobalt Company which bases its headquarter in Tongxiang, Jiaxing began to exploit mineral resources in Africa in 2006, its business scope ranges from cobalt, nickel and copper's exploration, smelting, transportation and new materials' deep processing. As a resource-seeking enterprise, Huayou Cobalt aggressively undertakes internationalization strategy, its mineral exploitation in Africa not only effectively warrants steady supply of downstream raw materials, lays firm foundation for enterprise's long-term development on one hand, but also helps the firm be ranked as No.1 cobalt producer quickly in China on the other hand.

Anli textile company which headquarters in Haining, Jiaxing invested in Vietnam to establish wholly owned subsidiary-Anli Textile (Vietnam) plant, the company has not only successfully expanded its market share in Asia Southeastern countries but also stabilized its market share in developed countries due to its effective 
avoidance of trade barriers through moving its domestic low-to-medium assembly line to Vietnam while keeping more advanced assembly line domestically, by that way the costs of its products are reduced greatly on one hand, and the company could also understand and meet customers' demand in Southeast Asian countries better due to its closer distance with customers on the other hand. Besides, relying on Vietnam plant's textile production to export to developed countries is an applicable way to circumvent trade barriers imposed such as high trade tariffs, quotas and even anti-dumping investigation since trade barriers are much lower for products exporting from Vietnam to developed countries.

Jiaxing Glass fiber weaving factory has set up joint venture with local company in Pakistan, Zhejiang Tongkun Group has set up joint venture with local company in Turkey, Zhejiang Yuli Plastic company has set up wholly owned subsidiary in Thailand, all those examples' practices follow western traditional FDI theories.

On 10th June, 2010, Zhejiang Hongxiang Construction Company was certified to undertake overseas project contracting. In May 2011, Hongxiang Company contracted with a construction firm in Kuala Lumpur to subcontract the construction of Kuala Lumpur national school project in Malaysia, the project's investment was amounted to RMB50 million, which symbolized that Hongxiang company had successfully entered project construction market in Malaysia. It also symbolized that Jiaxing's overseas project contracting has made a breakthrough of zero.

\subsection{Motives Do Not Follow Traditional FDI Theories}

Traditional FDI theories argue that absolute ownership advantages are the prerequisite of expanding overseas market, while strategic asset-seeking theory or asset exploration theory believe that firms can acquire complementary strategic asset to enhance their international competitiveness by reversed FDI mode (means FDI flow from developing countries to developed countries) if they do not own absolute ownership advantages yet. (Wang \& Yang, 2010) Recent international business theories originated from firms in emerging economies' practices have paid more attention to emerging multinational enterprises' competitive disadvantages which push firms to internationalize, that is: contrary to traditional ownership advantages, firms' motives to internationalize are to avoid competitive disadvantages due to solely running in domestic market on one hand (also called "push factors"), on the other hand, firms are attracted by overseas valuable strategic assets (called "pull factors"). In Jiaxing firms' case studies, there are also some examples supports those strategic assets exploration theories.

Zhejiang Kasen Group headquarters in Haining, Jiaxing is one of leading upholstered furniture and leather products manufacturers in China. Before 2008, Kasen was an OEM contractor for two Australian reputable furniture brands: Sleeping city and Everyday living. Hampered by 2008 global financial crisis, those two companies were broken in their capital chains, and then Kasen group decided to acquire those two firms' retail outlets in Australia. The profit of being an OEM contractor is just about $1.1 \%$ while the profit of being a company which owns the whole retail outlets is more than $15 \%$, thanks to that acquisition, Kasen's retail chain stores in Australia increased from 49 to 155, and its market coverage climbed to be ranked No.3 in Australia. Through that strategic assets exploration, Kasen group successfully upgrades its business mode from "made in China" to "made in China + distributed by Chinese firms", which advances the company's position in international value chain of furniture industry.

Zhejiang Yaweilang technology, Ltd headquarters in Haiyan, Jiaxing, the company is a highly efficient light emitting diode (LED) manufacturer, its main products include blue and green LED epitaxial wafers and chips for the LCD back lighting application of laptop, TV display, as well as general lighting. Jiaxing Yaweilong also founded American Inveenlux Corporation for cutting-edge technology and closer customers distance through acquisition, Jiaxing Aidier silk company acquired patent technology and assembly line, consolidated its competitive advantages in European market through acquisition of Italian Saierrini silk producing company.

\section{Internationalization Modes of Firms in Jiaxing}

\subsection{Stage Mode Theory of Internationalization}

Oviatt and McDougall stated in their milestone paper Toward a theory of international new ventures, "MNEs are believed by many people to evolve only after a period of domestic maturation and home market saturation (Caves, 1982; Porter, 1990). Empirical researchers have in the past found that large, mature MNEs and small exporters go through distinct stages in the development of their international business. They begin perhaps with an unsolicited foreign order, proceed sometimes through exporting and the development of an international division, and occasionally advance to the establishment of a fully integrated, global enterprise (Aharoni, 1966; Bilkey \& Tesar, 1977; Czinkota \& Johnston, 1981; Stopford \& Wells, 1972). This staged development of firm internationalization is described as an incremental, risk-averse and reluctant adjustment to changes in a firm or 
its environment (Johanson \& Vahlne, 1977, 1990). The process preserves routines that bind organizational coalitions, and recognizes the difficulty of gaining knowledge about foreign markets. Differences in language and culture and, in the past, the slow speed of communication and transportation channels between countries have inhibited the gathering of information about foreign markets and have increased the perceived risks of foreign operation." (Oviatt, 1994)

Stage model theory stemmed from middle 20th century, Johnson and Vahlne utilized enterprise behavior theory research method to analyze firms' internationalization activities, the theory argues that firms tend to expand international market slowly and step by step due to its lack of overseas market knowledge, its high uncertainty and risks avoidance factors constraints. The stage mode theory deems that firms' internationalization process follows several stages: pure domestic operation-export through intermediary-direct export-set up overseas sales branch-set up overseas subsidiary. Stage model theory considers that sufficient domestic operation is the prerequisite of overseas expansion, firms tend to invest in psychologically distance closed market firstly, its international market commitment is undertaken gradually, just like the waves in the water, only through this way, overseas market knowledge can be gained gradually, uncertainty and risks can be reduced, the stage model is also called Uppsala model or U-M mode. (Johnson \& Vahlne, 1977, 1990)

Jushi Group which headquarters in Tongxiang, Jiaxing mainly produces E-glass and C-glass fiberglass products, the company began its internationalization process in end 90s of last century, and it developed from initial small amount of exports to exports by foreign agents to set up its own sales branch in foreign countries gradually. Currently, Jushi Group has established overseas sales branches like Jushi France, Jushi India, Jushi Italy, Jushi Japan, Jushi Korea, Jushi Singapore, Jushi South Africa, Jushi Spain. Lately, Jushi Group just acquired American Gibson fiber-glass company and set up Jushi American Co., Ltd. Jushi Group has planned to set up more manufacturing plants in foreign countries to close the distance with its customers and provide them with better customized services.

\subsection{The Accelerated Mode of Internationalization}

In the beginning of 90s, 20th century, world economic integration and world trade began to assume new features which are facilitated by following factors: (1) accelerated speed of overseas information flow has reduced cross-border market's psychological distance, thus propelled further cross-border markets' integration; (2) reduced cost and improved efficiency of international traveling and communication have greatly strengthened firms' integrated cross-border operating capabilities; (3) international management experiences' availability in larger scope has enabled firms to acquire internationalization knowledge through recruitment and initial resource endowment; (4) the firms tend to be increasingly skilled in non-traditional corporate governance model, which help them effectively exploit their own unique and valuable resources by flexibly transferring and leveraging overseas external resources. In 1994, Oviatt and McDougall put forward a concept of New International Venture in their landmark thesis "Theories toward New International Venture" (Oviatt, et al., 1994). The theory argues that as deepening of world economic integration, social and technological advancement, firms do not have to follow stage mode to expand overseas, firms can obtain distinct competitive advantages by utilizing multi-countries resources and sell products to multi-countries just after the company was founded or in short time after its foundation. They defined International new venture as a business organization that, from inception, seeks to derive significant competitive advantage from the use of resources and the sale of outputs in multiple countries. The distinguishing feature of these start-ups is that their origins are international, as demonstrated by observable and significant commitments of resources (e.g., material, people, financing, time) in more than one nation. In other words, some "accelerated and frog-jump features" have occurred in firms' internationalization. (Oviatt, 1994)

Mathew (2006) introduced a brand new LLL (linkage, leverage, learning) model based on Dunning's OLI paradigm, which could better explain why firms in developing countries managed to accelerate internalization without ownership advantages, internalization advantages and location advantages. "First, it is by linkage and leverage, that internationalization is accelerated. It is the reaching out to sources of knowledge in the markets into which the firm is expanding that actually facilitates the accelerated expansion itself. It allows the learning process to be greatly speeded up. Thus linkage and leverage facilitates accelerated international expansion. Secondly, these strategies of linkage are perfectly adapted to the interconnected character of the global economy itself. Whereas earlier patterns of expansion sought to make all trans-border connections through the firm's own internal procedures, Many of the most successful latecomers from the Asia Pacific have begun their international career as a contractor to an incumbent MNE and then been drawn by this MNE to supply its regional operations across regional borders. This is a quite different pattern of international expansion and one which helps to account for the speed of the arrival of the latecomers. Thus linkage and leverage is well adapted to the 
interlinked character of the global economy. Third, the LLL framework of outward-oriented, resource-seeking internationalization via linkage and leverage, is an approach to internationalization that is eminently suited to the needs of latecomers and newcomers which initially lack resources in foreign countries." (Mathew, 2006) The model has laid theoretical groundwork for developing countries firms' accelerated internationalization. The theory means in principle that any firm which lacks resources in foreign countries can take advantage of the new features of the global economy, particularly its global interconnected character, to become an international player as well. The theory also reckoned any firm in developing countries including small-to-medium enterprises which lack strategic resources to expand overseas have the possibilities of expanding overseas market in an accelerated way through integration of linking, leveraging and learning effectiveness.

Among Jiaxing firms' case studies, some firms have taken full advantage of that globalization's interconnected trend, expanded foreign market in an accelerated way. Seriously affected by 2008 global financial crisis, many firms which owned cutting-edge technologies in western developed countries had to transfer their shares due to their poor financial situation. Therefore, equity participation or acquisition became easier for firms in Jiaxing to obtain strategic assets like advanced technology, equipment, brand and marketing distribution channels at lower cost.

Zhejiang Feierkang communication Ltd which was founded in Oct. 2010 is a company in the provision of fiber optic solutions and optical transceivers, it acquired Irish Firecomms Co., Ltd which is a global top plastic optical fiber links producer. Irish Firecomms was trapped in embarrassed situation of insolvency due to devastating Irish financial crisis although the company owned cutting edge technologies in plastic optical field. Zhejiang Feierkang company managed to occupy the fiber optical communication industrial height in very short time through acquisition of Irish Firecomms company. Zhejiang Feierkang company's international expansion model has fully reflected that accelerated international expansion approach which is mainly based on global resources integration and leveraging although the company is newly founded or just going through very short period after establishment. By combining its R\&D facilities in Ireland with its world-class manufacturing plant based on high-volume automated production and testing system in China, the company successfully reached synergy.

\section{Location Choices of Jiaxing Firms' Internationalization and "Go Global"}

Jiaxing firms should make right decisions on location choices of their FDI after fully considering their own international expansion motives, and purposefully choose location to enter. Internationalization motives determine location to enter, while location to enter must reflect internationalization motives' appeal. Therefore, different kinds of jiaxing firms with different purposes ought to have different positioning and FDI location choices rather than one location choice decision suits every different Jiaxing firm.

To firms engaged in traditional labor-intensive industries such as textile, fabric garments, their major concern is market expansion and efficiency pursuing, those firms' FDI location could choose to invest in developing countries which still fall behind China such as some Southeast Asian countries and countries in Africa on the basis of sustaining export to countries in Europe and North America since market demands to low-end products which are relative saturate in Chinese market are still large in those countries in addition to much lower labor cost, land cost and other production factors, thus, the combination of relative redundant production equipment and technology in China with lower-cost production factors in those countries will lead to more competent products. What's more, export to developed countries from other developing countries' manufacturing plants has become an applicable approach to circumvent trade barriers such as tariff, quota limits, etc since developed countries have imposed rigid trade barriers on products "made in China".

Jiaxing Anli Textile Company chose Vietnam as its FDI location two years ago, the company has set up manufacturing plant in Vietnam, and it moved its low-end production assembly line to Vietnam while keeping its top-end production equipment domestically. By that way, the company has effectively transferred its comparatively advantageous redundant production capabilities, which provided applicable way for company's restructuring and upgrading.

To some resource-seeking firms in Jiaxing, their FDI location should choose developing countries in Africa and Latin-America since those countries have abundant mineral resources with lower prices which are urgently needed by Zhejiang province. It is known that Zhejiang province is born with scarce natural resources, especially mineral resources. Therefore, going abroad to use foreign resources is a wise decision to solve problem of resource scarcity. Zhejiang Huayou cobalt company's investment of minerals in Congo (Kinshasa), Kasen Group's investment of agriculture in Brazil have provided good referents for other similar resource-seeking companies in Jiaxing.

To some strategic-asset seeking companies, their FDI location could choose developed western countries and 
Japan where invaluable strategic assets such as cutting-edge technology and know-how, international recognizable brand and mature distribution channels are available; those strategic assets could be gained through strategic alliance, joint venture or merger and acquisition forms. That is a brand-new, emerging FDI trend which flows from developing countries to developed countries, and can not be explained well by traditional OLI paradigm by John Dunning in international business field. Child and Rodrigues (2005) argued firms in developing countries' FDI to developed countries are mainly driven by both "push" and "pull" forces. The "push" forces refer to: the firms' survival and development are threatened by purely running in domestic market which are constrained by increasingly intensive competition, more complicated environment and non-stop shrinking profitability, while the "pull" factors means that differentiation advantages in overseas market bring great potential to complement Chinese firms cost-leadership advantages in domestic market, it is necessary and significant to access and acquire overseas advanced technology and expertise, international recognizable brand, and it is also very beneficial to access overseas entrepreneurial and management know-how and skills. By this location choice, firms in Jiaxing can reduce their risks and uncertainties of solely running domestically on one hand, they can also shorten the time of commanding key technological know-how and core competency and narrow the disparity in technology, management and experience between firms in China and firms in developed countries through acquisition of advanced technology, management experience and know-how on the other hand. Through that way, firms in Jiaxing upgrade from OEM contractor of western firms to independent firms which expand overseas market by their own brands and distribution channels, thus, Jiaixng firms' level and value are greatly enhanced, and its restructuring and upgrading are partially realized.

Zhejiang Feierkang company's FDI location choice of Ireland where a global top-level optical fiber receiver company headquartered enable it to acquire Firecomms' valuable strategic assets, through linkage and leverage, Zhejiang Feierkang occupies the global optical fiber industrial height in much less time period than depending on its own strengths; Zhejiang Kasen Group chose Australia and UK as its FDI location, since in those two countries exist some valuable marketing retail outlets to Kasen Group, through acquisition of those retail outlets, Kasen group successfully controlled those two countries' distribution channels in its own hand, which make it possible for the company upgrade from a OEM contractor of western firms to an independent firm which control the whole value chain, and expand the overseas market by its own brand name. Those FDI location choices have set up good examples for other firms which opt for strategic assets in Jiaxing.

\section{Problems Existed in Jiaxing Firms' Internationalization and "Go Global"}

Although lots of favorable achievements have been achieved in Jiaxing firms' internationalization and going global strategy's implementation, we must be soberly aware that there is still a long way to go for Jiaxing firms becoming truly multinational enterprise. Jiaxing firms still have lots of weakness and problems which urgently needed to be strengthened and solved in that intensively competitive internationalization process.

Analyzing objectively, Jiaxing firms are currently weak in innovation by their own capabilities, firms' decision making and management skills are still poor, while lacking of competent international managers are believed as the biggest impediment to their internationalization. Besides, relevant administration policies are not very appropriate for Jiaxing firms' further expansion in overseas market, little knowledge about host countries' legal system and business environment also causes potential threats to Jiaxing firms, some Jiaxing firms' success in overseas market also entail some hostile attack from local competitors in host countries, and what should not be ignored is that Jiaxing firms are plagued by host countries' political and legal corruption problems too (Yuan Hui, 2010).

\section{Problems Solution and Methods}

Solution to current problems and difficulties in current Jiaxing firms' internationalization process must be explored from both governmental macro policies perspective and individual enterprise micro action perspectives, can better results be achieved only two perspectives' are combined and integrated.

Relevant administration departments should serve Jiaxing firms' internationalization from wide range of their administrative services, the government should intensify their works on pre-direction and relevant projects introduction to any Jiaxing firm which exert willingness to expand overseas market, a broad range of information and knowledge about overseas market should be provided without delay. Particularly, more attention should be paid on directing Jiaxing firms to enter existing China's overseas economic and trade parks, through that way, Zhejiang firms internationalization's cluster and group advantages can be further unleashed. At the same time, administration departments should also provide Jiaxing firms with risk avoidance mechanisms such as political, legal risks' avoidance, continuously promote the risk prevention capabilities of Jiaxing firms. Besides, administration departments must make breakthrough in enterprise's fund raising service system, fund raising 
difficulties have become a long-standing problem for Jiaxing firms' internationalization, the relevant administration departments need to try multi-approaches to innovate its financial services and overcome those difficulties through flexible means.

Meanwhile, individual enterprise should also act forcefully from micro perspective, try to enhance its own competency to overcome and solve kinds of difficulties and problems in internationalization process. First of all, enterprises should learn to think about and make decisions and actions strategically about its internationalization from global resources linkage and leverage perspectives. The company could proactively identify and explore any possible business opportunity brought by globalization and interconnected character of world economy, learn to link with and leverage any available high-quality resources overseas and domestic through flexible networking, brand-new core competency could be cultivated through the integration of Jiaxing firms own capabilities with external resources gained from networking, global niche market could be quickly occupied through tailored innovative products and customized services, then Jiaxing firms' brand building and value chain upgrading could be realized from that beginning point. What's more, education and training also play very crucial roles in Jiaxing firms going global strategies, as mentioned above, lacking of competent international managers has constrained Jiaxing firms' further internationalization for long time, thus, employees' education and training issues must be seriously taken into consideration, education and training programs could be undertaken by on job or off-job forms, only by that way, can more competent international managers be cultivated. Yadong Luo and Huaichuan Rui (2009) put forward a concept called Ambidexterity which is a multidimensional term comprising co-evolution, co-competency, co-opetition, and co-orientation, they think firms in developing countries like China have stronger motives and abilities to build and leverage such ambidexterity to offset their late-mover disadvantages. They behave co-evolutionarily to deal with the external environment they face at home and abroad, leverage their co-competence (transactional and relational) to compete against their global rivals, develop co-opetitive (simultaneous cooperation and competition) ties with their business stakeholders, and maintain co-orientations (leveraging competitive advantages to bolster short-term survival and compensating competitive disadvantages for long-term growth. (Yadong Luo, 2009)

\section{Conclusion}

"Changing the development pattern, realize the industrial upgrading" is considered to be the biggest theme in post financial crisis era and the "twelfth five year planning period" in China. While implementing going global strategy, promoting Chinese firms' OFDI intensity steadily have become a key strategic means to speed up Jiaxing city's restructuring and upgrading, and realize the economy's steady growth.

By drawing on some representative case studies of Jiaxing firms which have successfully internationalize, the paper argues that motives of some Jiaxing firms' internationalization could be explained by traditional FDI theories, especially to those natural resources-seeking firms, market-seeking firms and efficiency-seeking firms. However, some Jiaxing firms' internationalization motives can not be explained by traditional FDI theories, because their FDI tend to flow from developing countries to developed countries, which is not the similar scenario that traditional FDI theories stemmed from, and those motives are particularly more obvious in large Jiaxing firms and high technology companies which put seeking valuable strategic assets as their first priority.

It is believed that different types of Jiaxing firms need to have different positioning and choices on FDI locations, every mode have its own advantages and disadvantages so that none can be universally applicable to all different types of Jiaxing firms. To market-seeking and efficiency-seeking firms in Jiaxing, their FDI location could choose Southeast Asian countries or countries with relative complete infrastructures in Africa, to natural resources seeking firms in Jiaxing, their FDI location could choose developing countries in Africa and Latin America where natural resources are born plentiful, to strategic assets seeking firms in Jiaxing, their FDI location should choose countries in West Europe, North America and Japan where valuable strategic assets are available.

Lots of delightful achievements have reached in Jiaxing firms' internationalization process, but there is still long way to go for Jiaxing firms to become truly multinational enterprise, Jiaixng firm's internationalization are still confronted with numerous challenges and problems. Better solution to those problems and difficulties should be probed from both government macro policies and individual enterprises' micro actions, only through those two approaches' combination and integration, can synergies be achieved. Referring to above mentioned representative Jiaxing firms which have successfully undertaken internationalization, further activities of Jiaxing firms' internationalization should mainly involve: forcefully promote the utilization and exploitation of overseas resources, establish more manufacturing plants and economic \& trade parks in foreign countries, vigorously propel the construction of overseas marketing distribution channels, acquire advanced technology, brand, 
knowledge and other strategic assets in foreign countries through merger and acquisition or strategic alliances forms, besides, international project subcontracting like turnkey project forms should also be attempted.

\section{References}

Aharoni, Y. (1966). The foreign investment decision process. Boston: Division of Research, Graduate School of Business Administration, Harvard University.

Andersen, O. (1993). On the internationalization process of firms: A critical analysis. Journal of International Business Studies, 24(2), 209-231. http://dx.doi.org/10.1057/palgrave.jibs.8490230

Autio, E., Sapienza, H. J., \& Almeida, J. G. (2000). Effects of age at entry, knowledge intensity, and limitability on international growth. Academy of Management Journal, 43(5), 909-924. http://dx.doi.org/10.2307/1556419

Bilkey, W. J., \& Tesar, G. (1977). The export behavior of smaller sized Wisconsin manufacturing firms. Journal $\begin{array}{llll}\text { of International } & \text { Business }\end{array}$ http://dx.doi.org/10.1057/palgrave.jibs.8490783

Bruton, G. D., Ahlstrom, D., \& Obloj, K. (2008). Entrepreneurship in emerging economies: Where are we today and where should the research go in the future. Entrepreneurship Theory and Practice, 32(1), 1-15. http://dx.doi.org/10.1111/j.1540-6520.2007.00213.x

Buckley, P. J., \& Ghauri, P. N. (Eds.). (1999). The Internationalization of the Firm. London: Thomson Business Press.

Buckley, P. J., Cross, A. R., Tan, H., Liu, X., \& Voss, H. (2008). Historic and emergent trends in Chinese outward direct investment. Management International Review, 48, 715-748. http://dx.doi.org/10.1007/s11575-008-0104-y

Caves, R. E. (1982). Multinational enterprise and economic analysis. Cambridge, MA: Cambridge University Press.

Child, J., \& Rodrigues, S. B. (2005). The internationalization of Chinese firms: A case for theoretical extension? Management and Organization Review, 1, 381-410. http://dx.doi.org/10.1111/j.1740-8784.2005.0020a.x

Czinkota, M. R., \& Johnston, W. J. (1981). Segmenting U.S. firms for export development. Journal of Business Research, 9, 353-65. http://dx.doi.org/10.1016/0148-2963(81)90012-6

Deng, P. (2004). Outward investment by Chinese MNEs: Motivations and implications. Business Horizons, 47, 8-16. http://dx.doi.org/10.1016/S0007-6813(04)00023-0

Dunning, J. H. (1980). Toward an eclectic theory of international production: Some empirical tests. Journal of International Business Studies, 11(1), 9-31. http://dx.doi.org/10.1057/palgrave.jibs.8490593

Dunning, J. H. (1988). The eclectic paradigm of international production: A restatement and some possible extensions. Journal of International Business Studies, 19(1), 1-31. http://dx.doi.org/10.1057/palgrave.jibs. 8490372

Dunning, J. H. (1993). Internationalizing Porter's Diamond. Management International Review, 33, 7-15.

Dunning, J. H. (1995). Multinational enterprises and the global economy. Reading, MA: Addison-Wesley.

Hanjie. (2010). Speeding up going global of firms in Zhejiang, promoting economy's restructuring and upgrading. Statistics Science and Practice, 8, 7-10.

Hymer, S. H. (1960). The International Operations of National Firms: A Study of Direct Foreign Investment. (PhD Dissertation). Published posthumously, Cambridge, Mass: The MIT Press, 1976.

Johanson, J., \& Vahlne, J. E. (1977). The internationalization process of the firm - A model of knowledge development and increasing foreign market commitment. Journal of International Business Studies, 8(1), 23-32. http://dx.doi.org/10.1057/palgrave.jibs.8490676

Johanson, J., \& Vahlne, J. E. (1990). The mechanism of internationalization. International Marketing Review, 7(4), 11-24. http://dx.doi.org/10.1108/02651339010137414

Li, L. (2003). Comparative research of two models of Internationalization. Issues about International trade, 4, 32-35.

Luo, Y. (2004). Coopetition in International Business. Copenhagen: Copenhagen Business School Press.

Luo, Y. (2007). From foreign investors to strategic insiders: Shifting parameters, prescriptions and paradigms for 
MNCs in China. Journal of World Business, 42(1), 14-36. http://dx.doi.org/10.1016/j.jwb.2006.08.009

Luo, Y., \& Tung, R. L. (2007). International expansion of emerging market enterprises: A springboard perspective. Journal of International Business Studies, 38, 481-498. http://dx.doi.org/10.1057/palgrave.jibs.8400275

Mathews, J. A. (2002). Dragon multinational: Towards a new model for global growth. New York: Oxford University Press.

Mathews, J. A. (2006). Dragon multinationals: New players in $21^{\text {st }}$ century globalization. Asia Pacific Journal of Management, 23, 5-27. http://dx.doi.org/ 0.1007/s10490-006-6113-0

Oviatt, B., \& McDougall, P. (1994). Toward a theory of international new ventures. Journal of International Business Studies, 25(1), 45-64. http://dx.doi.org/10.1057/palgrave.jibs.8400128

Porter. (1990). The competitive advantage of nations. New York: The Free Press.

Rui, H., \& Yip, G. (2008). Foreign acquisitions by Chinese firms: A strategic intent perspective. Journal of World Business, 43(2), 213-226. http://dx.doi.org/10.1016/j.jwb.2007.11.006

Stopford, J. M., \& Wells, L. T. (1972). Managing the multinational enterprise. New York: Basic Books.

Vernon, R. (1971). Sovereignty at Bay: The multinational spread of U. S. enterprises. New York: Basic Books.

Wang, F., \& Yang, Y. (2010). Research review of FDI location choices. Dynamics of Economy, 1, 111-116.

Yuan, H. (2009). International Constraints of Zhejiang Firms' going global. Zhejiang Statistics, 12, 19-21.

Zhao, W. (2010). Private enterprises' internationalization trend and practical suggestions-case studies of Zhejiang. Learning and Practice, 12, 5-11. 